\title{
Pancreatic Tumors in Children
}

\author{
Çocuklarda Pankreas Tümörleri
}

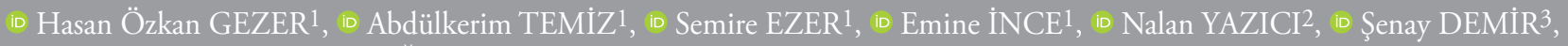
(1) Bermal HASBAY 4 , ib Pelin OĞUZKURT1

${ }^{1}$ Başkent University Faculty of Medicine, Department of Pediatric Surgery, Adana, Turkey

${ }^{2}$ Başkent University Faculty of Medicine, Department of Pediatric Oncology, Adana, Turkey

${ }^{3}$ Başkent University Faculty of Medicine, Department of Radiology, Adana, Turkey

${ }^{4}$ Başkent University Faculty of Medicine, Department of Pathology, Adana, Turkey

\section{ABSTRACT}

Objective: Pancreatic tumors in children are exceedingly rare and hence present diagnostic and therapeutic challenges to pediatric surgeons. In this study, we aimed to present our experiences and treatment outcomes related to these rare tumors.

Methods: The clinical data, laboratory investigations, radiological imaging, and the pathology and surgical details of patients with pancreatic tumors who were diagnosed between 2005 and 2019 were retrospectively reviewed.

Results: A total of 9 patients $(5$ men) were included in the study. The most common symptom at the time of presentation was vague abdominal pain. A pancreatic tumor was detected incidentally in 4 patients. All tumors were non-functional primary tumors. Histopathological diagnosis of these tumors were solidpseudopapillary tumors $(n=3)$, congenital pancreatic cysts $(n=3)$, pancreatoblastoma $(\mathrm{n}=1)$, rhabdomyosarcoma $(\mathrm{n}=1)$, and an undifferentiated carcinoma $(\mathrm{n}=1)$. In addition, 8 patients were treated surgically (through tumor excision, central pancreatectomy + distal pancreaticojejunostomy, distal pancreatectomy, and cystogastrostomy). Two deaths from tumor dissemination were recorded. The patients were followed-up at a mean duration of 72 months (range: 6-120 months).

Conclusion: Pediatric pancreatic tumors are rare and are usually benign in nature. They present symptoms that are often nonspecific. In non-metastatic cases, surgical tumor removal is the preferred method for the treatment. For most tumors, surgical resection is

\section{ÖZ}

Amaç: Çocuklarda son derece nadir görülen pankreas tümörlerinin tanı ve tedavisi pediatrik cerrahlar için halen zorluklar barındırmaktadır. Bu çalışmamızda pankreas tümörleri ile ilgili deneyimlerimizi ve tedavi sonuçlarımızı sunmayı amaçladık.

Yöntemler: 2005 ve 2019 yılları arasında, pankreas tümörü tanısı konulan, 0-18 yaş arası çocukların dosyaları geriye dönük olarak incelendi. Klinik, laboratuvar, radyolojik görüntüleme tetkikleri, patoloji ve ameliyat verileri elde edildi.

Bulgular: Çalışmamızda 5'i erkek toplam 9 hasta değerlendirildi. Hastaların en sık başvuru şikayeti karın ağrısıydı. Dört hastada ise pankreas tümörü tesadüfen tespit edildi. Tespit ettiğimiz tüm tümörler pankreasın fonksiyonel olmayan primer tümörleriydi. Tümörlerin histopatolojik tanıları ise solid-psödopapiller tümör $(\mathrm{n}=3)$, konjenital pankreas kisti $(\mathrm{n}=3)$, pankreatoblastoma $(\mathrm{n}=1)$, rabdomiyosarkom $(n=1)$ ve undifferansiye karsinom $(n=1)$ idi. Tümör eksizyonu (enükleasyon) ( $\mathrm{n}=5$ ), santral pankreatektomi + distal pankreaticojejunostomi $(\mathrm{n}=1)$, distal pankreatektomi $(\mathrm{n}=1)$, ve kistogastrostomi $(n=1)$ gibi yöntemler ile sekiz hasta cerrahi olarak tedavi edildi. Tümörün yaygınlığından iki hasta kaybedildi. Hastalar ortalama 8 yıl (6 ay-10 yıl) takip edildi.

Sonuç: Nadir görülen çocukluk çağı pankreas tümörleri, genellikle iyi huyludurlar. Başvuru nedeni sıklıkla hastalığa özgül olmayan semptomlardır. Metastatik olmayan olgularda, tümörün çıkarılması hastaların tedavisinde öncelikli olarak tercih edilmesi gereken yöntemdir. Tümörler çoğunlukla pankreasın gövde veya kuyruk
Address for Correspondence: Hasan Özkan GEZER, Başkent University Faculty of Medicine, Department of Pediatric Surgery, Adana, Turkey

E-mail: hozkangezer@yahoo.com.tr ORCID ID: orcid.org/0000-0002-4635-2613
Received: 27.11.2019

Accepted: 07.01.2020

Cite this article as: Gezer HÖ, Temiz A, Ezer S, İnce E, Yazıcı N, Demir Ş, Hasbay B, Oğuzkurt P. Pancreatic Tumors in Children. Bezmialem Science 2021;9(1):29-34. 
the optimal treatment that may be successfully performed with low morbidity rate when the lesion is either in the body or in the tail of the pancreas. The long-term outcomes with this approach are generally good.

Keywords: Pancreatic, pediatric, neoplasm, cancer, surgery kısmında yerleştiğinden cerrahileri yüz güldürücüdür ve düşük morbidite ile sonuçlanır. Tam olarak tümörün çıkarılabildiği olgularda uzun vadeli sonuçlar genellikle iyidir.

Anahtar Sözcükler: Pankreas, pediatrik, neoplazm, kanser, cerrahi

\section{Introduction}

Pancreatic tumors are extremely rare in children and young adults. Although solid-pseudopapillary tumors (SPT) are more common in adolescence, pancreatoblastoma (PBs) remain the most commonly encountered tumors in the first decade of life $(1,2)$. Other less common tumors, such as neuroblastoma, neuroendocrine tumors, acinar cell carcinoma, rhabdomyosarcoma (RMS), lymphoma, and hemangioendothelioma have also been reported $(1,3)$. The incidence of pediatric pancreatic tumors, irrespective of their histology, has increased over the past 3 decades, with the advancements in the imaging methodologies. However, no significant changes have been reported in therapeutic approaches during this time period $(1,4)$. Surgery remains the cornerstone of any curative approach, with the exception of lymphoma, although the associated morbidity rates are $30 \%-40 \%$ (5). Pancreatic tumors in children continue to be challenging for pediatric surgeons, often due to insufficient experience in the management of such patients (6). The aim of the present study was to review our institutional experiences of pancreatic tumors in children, with a particular focus on tumor presentation, diagnosis, treatment, and outcomes.

\section{Method}

Our local ethics committee approved this study (project no: KA19/377). All patients and their families were fully informed about the study and they consented to their participation. This retrospective study included 9 patients with pancreatic tumors identified from the histopathology reports at the Department of Pediatric Surgery, Başkent University and the Faculty of Medicine between 2005 and 2019. The clinical features, diagnostic methods, and the treatment and results were accordingly recorded.

\section{Results}

Nine patients ( 4 girls, 5 boys) of median age at the time of surgery of 11 years (age range: 1-17 years) were identified from the medical charts and notes. The patient data (i.e., age, sex, presenting symptoms, tumor location, tumor nature and number, tumor size $(\mathrm{cm})$, tumor type, treatment/in the order of time, and outcomes) are summarized in Table 1.

A 15-year-old male patient (case \#1) was investigated in the external center for abdominal pain. His magnetic resonance imaging (MRI) revealed a heterogeneous mass of approximately $14.3 \times 10.2 \mathrm{~cm}$ in diameter at the lateral segment of the left lobe of the liver. A needle biopsy was performed, and the subsequent pathology revealed a hepatoblastoma. The patient was referred to the pediatric oncology department of our hospital for further treatment. Patient $\alpha$-fetoprotein (AFP) levels at the time of diagnosis were found to be elevated: $12125>8.00 \mathrm{ng} / \mathrm{mL}$. The patient received chemotherapy, with a preliminary diagnosis of hepatoblastoma. The patient was examined 4 months later because of a significant non-reduction in the tumor mass size $(11.0 \times 8.5 \mathrm{~cm})$ despite chemotherapy and the persistence of AFP levels (17358 >8.00 ng/mL). A "left hepatectomy" was accordingly decided. During surgery, a mass originating in the pancreas, with no connection to the liver, was detected and then completely excised with enucleating. The pathology report declared an undifferentiated carcinoma. Although postoperative radiotherapy was provided, the patient died due to progressive metabolic disease after 18 months.

A 6-year-old boy (case \#2) was admitted to our clinic for vague abdominal pain. A solid mass measuring $11 \mathrm{~cm}$ in diameter was detected at the head of the pancreas. A needle biopsy reported a pancreaticoblastoma. The patient received chemotherapy and subsequently underwent surgery to remove the residual mass measuring $1.5 \mathrm{~cm}$ by total tumor excision. This case was classified as an uneventful recovery.

Only 1 case of RMS was registered (case \#3) that originated from the pancreas. The patient had distant metastasis in the bone marrow, skin, and prostate at the time of diagnosis, as assessed by needle biopsy. Although several treatment methods were performed by the pediatric oncology department, including chemotherapy, radiotherapy, and even autologous bone marrow transplantation, the patient died 18 months after the treatment initiation.

Of the 3 patients with solid SPTs, 1 (case \#6) presented with abdominal pain, while 2 other SPTs (case \#4 and case \#5) were detected incidentally. Two of these 3 patients underwent needle biopsy for diagnosis. The SPT diagnosis in the other case was assessed, based on the appearance of the mass, using ultrasound (US) and computed tomography (CT), and completed with MRI for all cases. During US, hypoechoic, cystic, or cystic-solid masses with clear margins were noted. CT images revealed a cystic mass at the pancreatic neck, enhancing peripherally after contrast administration. MRI revealed hemorrhagic content in the cystic portion and diffusion restriction of the enhancing thick wall of the mass (Figure 1). None of the patients showed either suspicious regional nodes or distant metastases. In addition, cases \#4, 5, and 6 underwent mid-pancreatectomy distal pancreaticojejunostomy, tumor excision, and distal pancreatectomy, respectively (Figure 2). 


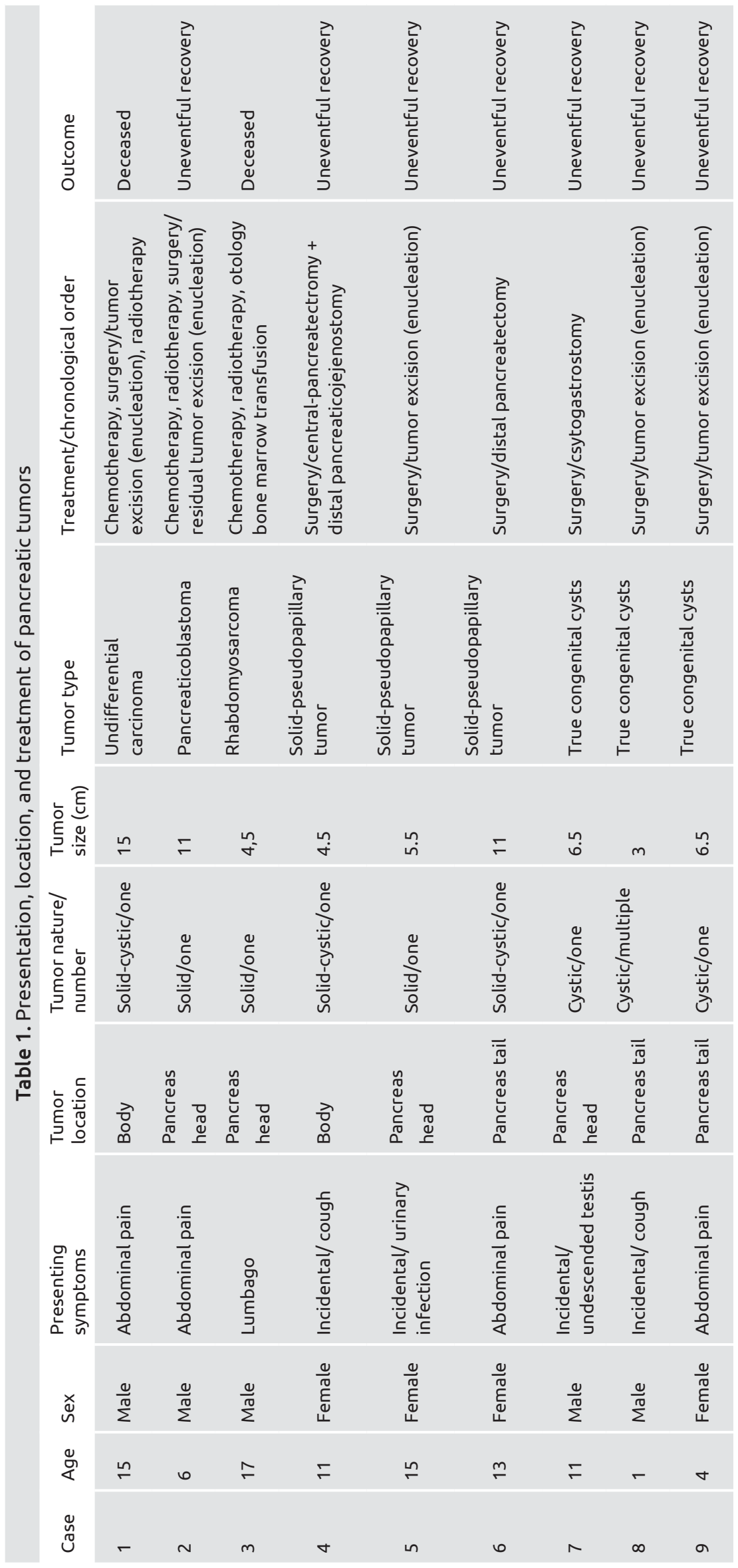

Congenital pancreatic cysts were detected in 3 patients (case \#7, 8, and 9). Multiple cysts were detected in a 3-year-old girl (case \#9), with all cysts completely removed. In case \#7, the cysts were treated by a internally drainage method through cystogastrostomy, as the cyst was located at the head of the pancreas.

\section{Discussion}

Pediatric pancreatic tumors are much rarer than adult ones and are generally benign (albeit some have malignant potential) as well as have a different histopathological basis $(2,3)$. In our study, benign $(n=6)$ and malignant tumors $(n=3)$ were encountered. The most common tumor of the pancreas is solid SPT, which accounts for $2 \%-3 \%$ of all pancreatic tumors (7). The male to female ratio is $1: 9.5$, and, in approximately $15 \%$ of the patients, it has a low-grade malignant potential with properties of invasion or metastasis (8). Most cases are located in the tail of the pancreas (9). However, in this study, 2 cases were reported in the body. This tumor frequently presents with nonspecific symptoms, including abdominal pain due to slow tumor growth, which is not unusual for these tumors to be detected incidentally by US (4). In our study, one patient was diagnosed while being investigated for abdominal pain and the remaining were diagnosed incidentally for unrelated reasons. In all patients, pancreatic and liver enzymes, as well as tumor markers were within normal limits, as reported previously in the literature (4). It has been reported that a mass with sharp margins, large, hypoechoic or echogenic, solid-cystic or pure solids, including internal septation or calcification is observed during US, whereas CT usually presents a well-encapsulated mass, with varying degrees of contrast (8). Percutaneous fine-needle aspiration was also reported in the diagnoses with $72 \%$ accuracy (8). Metastasis was not observed in any of our patients; however, in the literature, the liver, lymph node, and peritoneal metastasis have been reported. However, the presence of these metastasis does not affect survival (8). Despite complete tumor regression reported without requiring surgical intervention (10), surgical removal is the preferred treatment approach that is possible in most cases, even for large tumors (8). In 1 of our patients (case \#4), a central pancreatectomy and 
distal pancreaticojejunostomy was performed because the tumor was located at the neck of the pancreas. Although disseminated disease is not a negative indicator for survival, all patients required continued follow-up for surveillance for late metastasis or local recurrence (8).

True congenital pancreatic cysts are extremely rare in children and difficult to distinguish from other pancreatic cysts, such as retention, duplication, pseudocyst, neoplastic, and parasitic cysts. It is also difficult to distinguish them pathologically from retention and duplication cysts (11). Although these cysts are mostly reported as unilocular and located in the body/tail of the pancreas (12), we detected multiple cysts in 1 patient, and cysts located at the head of the pancreas in another patient. A past study has reported that cysts usually present with symptoms such as abdominal distension, vomiting, jaundice, or pancreatitis in patients aged $<2$ years of age (12). However, the diagnosis was made incidentally in a patient aged $<2$ years of age. When a cystic tumor of the pancreas is recognized, the laboratory data, clinical features, and modern imaging techniques are insufficient to distinguish them from other cystic lesions (11). Therefore, every effort should be made to exclude a history of acute pancreatitis, because pancreatic pseudocysts remain the single-most common cystic pancreatic mass (13). No trauma histories were noted in our patients. Pathologically, the cysts in all 3 patients (case $\# 7,8$, and 9) were covered with cuboidal epithelium, and 1 patient (case \#9) showed pancreatic tissues on the cyst wall. The literature reports that these cysts may also have had high amylase levels, as in the present patient (11). It has also been reported that surgical excision, cyst marsupialization with drainage, and aspiration were used in the treatment of these congenital cysts. However, despite aspiration having been used previously, it is not recommended presently (14). The cyst was treated through the internal drainage method in a patient through cystogastrostomy because the cyst was located at the head of the pancreas.

PBs comprises only $0.5 \%$ of pancreatic non-endocrine tumors and share similar histological and morphological features with hepatoblastomas that secrete AFP $(6,15)$. Although reported with high prevalence in past studies (6), in the present study, only one case of this type of malignancy was recorded in a child presenting with a large abdominal mass (case \#2). PBs affects a similar age group with hepatoblastoma. The tumor usually results in a satisfactory clinical response when using the same chemotherapeutic agents as for hepatoblastoma. $\mathrm{PB}$ is less aggressive in children when compared with that in adults; therefore, surgery is the optimal treatment and complete resection of the tumor provides the best prognosis (6). Moreover, adjuvant chemotherapy is not recommended when the tumor can be completely excised (15). However, we performed a truecut biopsy in case \#2 with a large mass located in the head of the pancreas and treated him with chemotherapy and radiotherapy. Approximately 24 months since the treatment initiation, the remaining $1.5-\mathrm{cm}$ residual mass was totally removed with enucleation. The AFP levels may serve as a valuable tumor marker for preoperative diagnoses, and it can even indicate therapeutic effects and postoperative recurrences in PB patients (15). AFP
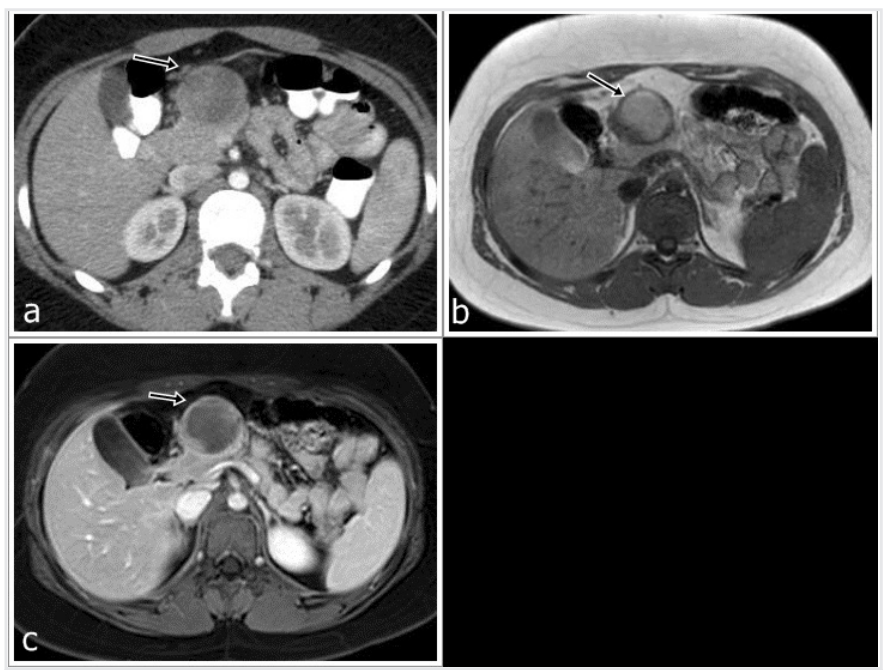

Figure 1. CT images detected a cystic mass at the pancreatic neck that enhanced peripherally after contrast administration. MRI showing the hemorrhagic content in the cystic part and the diffusion restriction of the enhancing thick wall of the mass. a) CT image showing the cystic mass at the pancreatic neck, with peripheral irregular enhancement after contrast administration. b) Axial T1weighted MRI showing hyper-intense hemorrhagic content of the mass. c) Axial T2-weighted image showing the cystic portion and the peripheral enhancing thick wall of the mass

CT: Computed tomograpy, MRI: Magnetic resonance imaging
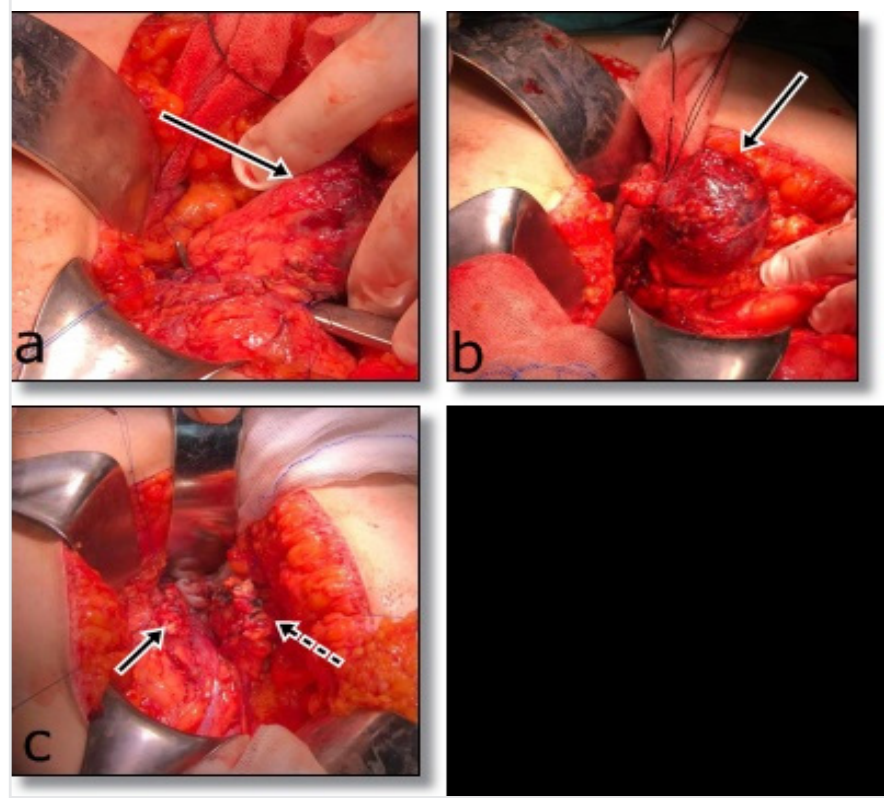

Figure 2. Surgery pictures: a) The presence of a mass located in the neck of the pancreas during the operation and the moment of suspension of the pancreas. The arrow indicates the tumor. b) The moment when the mass was to be separated from the head of the pancreas with limited pancreatic tissue remaining. The arrow indicates the tumor. c) Image of the proximal (normal arrow) and distal (dashed arrow) pancreas tissues after removal of the mass through central pancreatectomy 
has been used as a marker in the follow-up period after residual mass excision and found to be normal.

RMS is a primary malignancy that arises from the embryonic mesenchyme, with the potential to differentiate into skeletal muscles (16). RMS constitutes approximately 50\% of all soft tissue sarcomas in children. RMS of the biliary tree is extremely rare (approximately $0.5 \%$ ) and encountered mostly in infants and children (17), as has been described in 4 patients in relation to the gallbladder (18). In our study, RMS in the pancreas was observed via true-cut biopsy in case \#3 with disseminated disease (i.e., distant metastasis in the bone marrow, skin, and prostate regions). Despite providing intense treatments, including chemotherapy, radiotherapy, and a bone marrow transfusion, the patient died within 18 months of initiating the treatment.

Although endocrine tumors were not observed in this study, glucagon-, gastrin-, and somatostatin-secreting pancreatic tumors have all been reported in the pediatric age groups (19). Pancreatic endocrine tumors are mainly solitary and 90\% benign, which often occurs in children aged $>4$ years (19). Specific hormones, over-secreted by the tumor, such as insulin, glucagon, gastrin, or somatostatin, determine the clinical features of these tumors. In addition, although the involvement of pancreatic Burkitt lymphomas (not observed in our study) is $<1 \%$, it should be distinguished from pancreatic adenocarcinoma because chemotherapy is typically more effective for pancreatic lymphoma than pancreatic adenocarcinoma (20).

In this study, we employed the use of abdominal US, followed by CT, as the initial imaging method. Enhanced CT is an extremely useful diagnostic technique. In CT images, the cystic portion of the tumors demonstrated no enhancement, but the solid portions showed a slight enhancement in the arterial phase and marked enhancement in the portal venous phase (21). When compared with MRI, CT has inherent limitations in detecting certain tissue characteristics, such as hemorrhage, cystic degeneration, or integrity of the tumor capsule, which are the factors that typically suggest pancreatic tumors (21). Because of its superior contrast resolution, MRI scans better display capsule and intratumoural hemorrhages when compared with CT scans. In cases of obstructive jaundice, endoscopic retrograde cholangiopancreatography with stent placement can be used to relieve biliary tract obstructions (21). In some special cases, an upper gastrointestinal contrast study may be used for the differentiation of duodenal duplication cysts from pancreatic head-located masses (22).

It has been reported that cystic pancreatic masses of $<3 \mathrm{~cm}$ without any solid component, which can be followed-up safely through imaging (13). The majority of children with pancreatic tumors present with isolated lesions and are good surgical candidates. Primary surgical excision, without requiring a definitive preoperative tissue diagnosis, is also recommended (22). Masses located in the head of the pancreas must be treated by pancreaticoduodenectomy, with preservation of the pylorus or the Whipple procedure, to achieve macroscopic resection while avoiding complications and sparing the endocrine pancreas. Central tumors can be treated by central-pancreatic resection, although this surgery is complicated in terms of pancreatic and biliary fistulas. Tumors located in the tail of the pancreas can be easily removed through caudal pancreatectomy (7). A laparoscopic approach for pediatric pancreatic tumors has been reported previously (6), but it could not be performed in our study. For children who present with less typical lesions, tissue biopsy (percutaneous or laparoscopic) may be necessary to guide the treatment approach.

\section{Conclusion}

Pancreatic tumors are rare in children. Although these tumors may have malignant potential, they are usually benign. In the absence of a biologically active endocrine tumor, pancreatic tumors are typically diagnosed with nonspecific symptoms or diagnosed incidentally. In isolated pancreatic tumors with a trunk or tail tumor localization, primary resection appears to be the most appropriate treatment choice, which resulted in encouraging the prognoses for patients.

\section{Ethics}

Ethics Committee Approval: Our local ethics committee approved this study (project no: KA19/377).

Informed Consent: All patients and their families were fully informed about the study and they consented to their participation.

Peer-review: Externally peer reviewed.

\section{Authorship Contributions}

Surgical and Medical Practices: H.Ö.G., A.T., S.E., E.İ., N.Y., Ş.D., B.H., P.O., Concept: H.Ö.G., Design: H.Ö.G., E.İ., Data Collection or Processing: H.Ö.G., A.T., S.E., E.İ., N.Y., Ş.D., B.H., P.O., Analysis or Interpretation: H.Ö.G., A.T., S.E., Literature Search: H.Ö.G., A.T., S.E., E.İ., N.Y., Ş.D., B.H., P.O., Writing: H.Ö.G.

Conflict of Interest: No conflict of interest was declared by the authors.

Financial Disclosure: The authors declared that this study received no financial support.

\section{References}

1. Scandavini C, Valente R, Rangelova E, Segersvärd R, Arnelo U, Permert J, et al. Pancreatectomies for pancreatic neoplasms in paediatric and adolescent age: A single institution experience. Pancreatology 2018;18:204-7.

2. Office for National Statistics (2011) Cancer Statistics Registrations, England (Series MB1), No. 42. http://www.ons.gov.uk/ons/rel/ vsob1/cancer-statistics-registrations-england-series-mb1-/no-422011/sty-pancreatic-cancer.html. Accessed 20 Mar 2015.

3. Yu DC, Kozakewich HP, Perez-Atayde AR, Shamberger RC, Weldon CB. Childhood pancreatic tumours: A single institution experience. J Pediatr Surg 2009:44:2267-72. 
4. Rebhandl W, Felberbauer FX, Puig S, Paya K, Hochschorner S, Barlan M, et al. Solid-pseudopapillary tumour of the pancreas (Frantz tumour) in children: report of four cases and review of the literature. J Surg Oncol 2001;76:289-96.

5. Hachiyaa M, Hachiyaa Y, Mitsuia K, Tsukimoto I, Watanabe K, Fujisawa T. Solid, cystic and vanishing tumours of the pancreas. J Clin Imag 2003;27:106-8.

6. Nasher O, Hall NJ, Sebire NJ, de Coppi P, Pierro A. Pancreatic tumours in children: diagnosis, treatment and outcome. Pediatr Surg Int 2015;31:831-5.

7. Muller CO, Guérin F, Goldzmidt D, Fouquet V, Franchi-Abella S, Fabre M, et al. Pancreatic resections for solid or cystic pancreatic masses in children. J Pediatr Gastroenterol Nutr 2012;54:369-73.

8. Seo HE, Lee MK, Lee YD, Jeon SW, Cho CM, Tak WY, et al. Solid-pseudopapillary tumour of the pancreas. J Clin Gastroenterol 2006;40:919-22.

9. Coleman KM, Doherty MC, Bigler SA. Solid-pseudopapillary tumour of the pancreas. Radiographics 2003;23:1644-8.

10. Hachiyaa M, Hachiyaa Y, Mitsuia K, Tsukimoto I, Watanabe K, Fujisawa T. Solid, cystic and vanishing tumours of the pancreas. J Clin Imag 2003;27:106-8.

11. Al-Salem AH, Matta H. Congenital pancreatic cyst: diagnosis and management. J Pediatr Gastroenterol Nutr 2014;59:38-40.

12. Onur MR, Bakal U, Kocakoc E, Tartar T, Kazez A. Cystic abdominal masses in children: a pictorial essay. Clin Imaging 2013;37:18-27.

13. Megibow AJ. Update in imaging of cystic pancreatic masses for gastroenterologists. Clin Gastroenterol Hepatol 2008;6:1194-7.
14. Kazez A, Akpolat N, Kocakoc s, Parmaksiz ME, Köseoğullari AA. Congenital true pancreatic cyst: a rare case. Diagn Interv Radiol 2006; 12:31-3.

15. Xu C, Zhong L, Wang Y, Wang W, Yang Z, Kang X, et al. Clinical analysis of childhood pancreatoblastoma arising from the tail of the pancreas. J Pediatr Hematol Oncol 2012;34:177-81.

16. Hayes-Jordan A, Andassy R. Rhabdomyosarcoma in children. Curr Opin Paediatrics 2009;21:373-8.

17. Nemade B, Talapatra K, Tunuja S, Shirpad B, Muckaden M, Laskar $\mathrm{S}$. Embryonal rhabdomyosarcoma of the biliary tree mimicking a choledochal cyst. J Cancer Res Ther 2007;40-2.

18. Shirafkan Md A, Boroumand Md N, Komak Md S, Duchini Md A, Cicalese Md L. Pancreatic pleomorphic rhabdomyosarcoma. Int J Surg Case Rep 2015;13:33-6.

19. Teixeira RC, Nico MM, Ghideti AC. Necrolytic migratory erythema associated with glucagonoma: a report of two cases. Clinics 2008;63:267-70

20. Sağlam M, Yılmaz MI, Mas MR, Taşcị I, Ors F, Sönmez A, et al. A case of pancreatic Burkitt lymphoma: radiological findings. Diagn Interv Radiol 2009;15:39-42.

21. Guo N, Zhou QB, Chen RF, Zou SQ, Li ZH, Lin Q, et al. Diagnosis and surgical treatment of solid pseudopapillary neoplasm of the pancreas: analysis of 24 cases. Can J Surg. 2011;54:368-74.

22. Freelove R, Walling AD. Pancreatic cancer: diagnosis and management. Am Fam Physician 2006;73:485-92. 